\title{
Connectivity of wood thrush breeding, wintering, and migration sites based on range-wide tracking
}

\author{
Calandra Q. Stanley, ${ }^{*} \dagger \neq$ Emily A. McKinnon, ${ }^{*} \ddagger \emptyset$ Kevin C. Fraser, ${ }^{*}$ Maggie P. MacPherson, ${ }^{*}$ \\ Garth Casbourn, ${ }^{*}$ Lyle Friesen, $\neq$ Peter P. Marra,$\dagger$ Colin Studds, $\dagger^{* *}$ T. Brandt Ryder,$\dagger$ \\ Nora E. Diggs, $\uparrow$ and Bridget J. M. Stutchbury* \\ ${ }^{*}$ Department of Biology, York University, Toronto, M3J 1P3, Canada \\ †Smithsonian Conservation Biology Institute, Migratory Bird Center, National Zoological Park, Washington, D.C. 20013, U.S.A. \\ ‡Canadian Wildlife Service, Ontario Region, 867 Lakeshore Road, Burlington, Ontario, Canada
}

\begin{abstract}
Many migratory animals are experiencing rapid population declines, but migration data with the geographic scope and resolution to quantify the complex network of movements between breeding and nonbreeding regions are often lacking. Determining the most frequently used migration routes and nonbreeding regions for a species is critical for understanding population dynamics and making effective conservation decisions. We tracked the migration of individual Wood Thrushes (Hylocichla mustelina) $(n=$ 102) from across their range with light-level geolocators and, for the first time, quantified migration routes and wintering regions for distinct breeding populations. We identified regional and species-level migratory connectivity networks for this declining songbird by combining our tracking results with range-wide breeding abundance estimates and forest cover data. More than 50\% of the species occupied the eastern wintering range (Honduras to Costa Rica), a region that includes only one-third of all wintering habitat and that is undergoing intensive deforestation. We estimated that half of all Wood Thrushes in North America migrate south through Florida in fall, whereas in spring approximately $73 \%$ funnel northward through a narrow span along the central U.S. Gulf Coast $\left(88-93^{\circ} \mathrm{W}\right)$. Identifying migratory networks is a critical step for conservation of songbirds and we demonstrated with Wood Thrushes bow it can bighlight conservation hotspots for regional populations and species as a whole.
\end{abstract}

Keywords: Central America, geolocator, Hylocichla mustelina, migration network, migration route, migratory connectivity, tropical deforestation

Conectividad de Sitios de Reproducción, Invierno y Migración del Zorzal con Base en Rastreo de Cobertura Amplia

Resumen: Muchos animales migratorios están experimentando declinaciones poblacionales rápidas, pero la información migratoria con el enfoque geográfico y la resolución para cuantificar la red completa de movimientos entre regiones reproductivas y no reproductivas con frecuencia es carente. Determinar las rutas y las regiones no-reproductivas usadas con mayor frecuencia por una especie es crítico para entender las dinámicas poblacionales y bacer decisiones de conservación efectivas. Rastreamos la migración individual de zorzales (Hylocichla mustelina) $(n=102)$ a lo largo de su extensión con geolocalizadores de bajo nivel $y$, por primera vez, cuantificamos la conectividad de las rutas migratorias y las regiones de invierno para poblaciones reproductivas diferentes. Identificamos redes de conectividad migratoria regionales y a nivel de especie para esta ave canora en declive al combinar nuestros resultados de rastreo con los estimados de abundancia reproductiva de cobertura amplia y los datos de cubierta forestal. Más del 50\% de las especies ocuparon la cobertura occidental de invierno (de Honduras a Costa Rica), una región que incluye sólo un tercio de todo el hábitat de invierno y que está sometida a una deforestación intensiva. Estimamos que la mitad de los zorzales en América del Norte migran al sur por Florida en el otoño, mientras que en la primavera

$₫$ Address correspondence to Emily A. McKinnon, email emilymck@yorku.ca

$\ddagger$ Both the authors contributed equally.

ICurrent address: Department of Ecology and Evolutionary Biology, Tulane University, New Orleans, LA 70118, U.S.A.

** Current address: Department of Geography and Environmental Systems, 221 Sondbeim Hall, University of Maryland, Baltimore County Paper submitted September 6, 2013; revised manuscript accepted April 24, 2014. 
aproximadamente el $73 \%$ atraviesan un camino estrecho a lo largo del centro de la costa del Golfo en los Estados Unidos $\left(88-93^{\circ} \mathrm{W}\right.$ ). Identificar las redes migratorias es un paso crítico para la conservación de las aves canoras y demostramos con los zorzales cómo puede resaltar sitios de importancia para la conservación para poblaciones regionales y para la especie entera.

Palabras Clave: América Central, conectividad migratoria, deforestación tropical, geolocalizador, red migratoria, ruta de migración, Hylocichla mustelina

\section{Introduction}

Conserving migratory species is challenging because threats often occur at unknown locations, thousands of kilometers away from breeding sites (Martin et al. 2007). Dozens of species of migratory landbirds have experienced steep population declines driven by multiple stressors at temperate breeding sites, along migration routes, and on their nonbreeding (hereafter wintering) grounds (Faaborg et al. 2010). One of the biggest challenges in migratory songbird conservation has been determining the link between well-studied temperate breeding populations and threats elsewhere in their life cycle (Sherry \& Holmes 1996; Sillett et al. 2000) so that conservation actions can occur where they are most needed and throughout the range of at-risk populations. Until recently, there was little or no information on where specific breeding populations migrate to, or how they get there (i.e., migratory connectivity) (Webster et al. 2002; Marra et al. 2006). The miniaturization of light-level geolocators small enough for songbirds has provided a breakthrough for studies of migratory connectivity (Stutchbury et al. 2009). Geolocators currently provide the most precise (within approximately $300 \mathrm{~km}$ in latitude and approximately $150 \mathrm{~km}$ longitude) means to track small birds throughout their annual cycle, which provides an unprecedented opportunity to quantify patterns of connectivity for declining migratory songbirds (McKinnon et al. 2013a).

Patterns of migratory connectivity between breeding and wintering sites of migratory animals can be described qualitatively on a gradient from strong to weak (Webster et al. 2002). If breeding populations segregate on the wintering grounds, then migratory connectivity is strong (Supporting Information) and habitat loss at specific wintering regions should have a large impact on corresponding breeding regions (Rubenstein et al. 2002). In contrast, if breeding populations mix extensively in the nonbreeding season (Supporting Information), then migratory connectivity is weak and habitat loss in one nonbreeding region is expected to have a diffuse effect on breeding populations (Webster et al. 2002).

Migratory connectivity studies based on recaptures of banded birds in locations other than where they were banded and intrinsic markers (e.g., genetic structure) show moderate to strong connectivity at broad continental (Norris et al. 2006; Ambrosini et al. 2009; Irwin et al. 2011) and subcontinental (Rubenstein et al. 2002) scales. Two recent studies that tracked individual Pur- ple Martins (Progne subis) and Bobolinks (Dolichonyx oryzivorus) showed breeding-wintering migratory connectivity was very weak and extensive mixing of North American breeding populations on the wintering grounds in South America (Fraser et al. 2012; Renfrew et al. 2013). Therefore, for these species, threats to wintering habitat will be similar for all breeding populations. Connectivity of migratory routes has been rarely studied because indirect methods, such as stable isotope or genetic analyses, cannot provide information on start-to-finish migratory routes of songbirds. Many species of songbirds exhibit loop migration, where spring and fall routes occur along different longitudes (McKinnon et al. 2013a), but for most species it is unknown to what extent migration routes vary among breeding populations (but see Fraser et al. 2013).

A pattern of strong migratory connectivity can be maintained by segregation of migration routes by breeding populations due to major geographical barriers (Delmore et al. 2012; Fraser et al. 2012) or differences in ancestral migration routes (Bairlein et al. 2012; Delmore et al. 2012). A leap-frog pattern of migratory connectivity, where birds breeding farther north winter farther south (Newton 2008), can be a result of a latitudinal gradient in winter habitat quality if the costs of migrating farther are mitigated by higher quality habitat (Bell 1997). Strong connectivity can also result from parallel migration, in which breeding longitude and winter longitude of individuals are positively correlated (Newton 2008). Segregation of migration routes, regardless of the mechanism, means that threats along these routes could differ among breeding populations.

Migratory connectivity can be described through delineation of a migratory network. The network is used to identify and quantify the connections between breeding, migration, and wintering sites (Taylor \& Norris 2010). The network can then be used to develop spatially realistic population models (Marra et al. 2006; Taylor \& Norris 2010) to predict effects of threats in one part of the migratory network on the species as a whole. The models show theoretically that habitat loss in one region can have a ripple effect throughout the network and can affect populations that are not directly connected to the region experiencing habitat loss. Networks can also be used to identify habitat critical for conservation by highlighting regions used by a large proportion of the species overall (Martin et al. 2007). There are diverse theoretical approaches for understanding spatial networks 
(e.g., Runge \& Marra 2005; Marra et al. 2006; Taylor \& Norris 2010), but empirical data to quantify migratory networks for songbirds are still lacking.

Migratory networks can be useful for conservation at multiple scales. A migratory network based on a single regional population is informative for conservation organizations and government environmental agencies, which are often responsible for developing policies to safeguard specific populations (e.g., at the level of the state, province, and ecoregion). Certain populations also may be important to conserve because of local adaptations (Lesica \& Allendorf 1995). Species-level conservation requires identification of the habitat most likely to benefit the species overall (Martin et al. 2007). A speciesscale network can be used to quantify which migratory routes and wintering sites are used by the greatest proportion of individuals. A species-level network is also a prerequisite for testing hypotheses regarding the overall mechanisms for population declines and for predictive modeling (Taylor \& Norris 2010).

We tracked the round-trip migrations of individual Wood Thrushes (Hylocichla mustelina) by deploying geolocators at 7 breeding and 4 wintering sites. Like many other forest songbirds, Wood Thrush populations have declined (1.8\%/year) since 1966 (Sauer et al. 2012). Our objective was to provide a model of how migration data can be used to develop migratory networks and inform conservation measures. We created the first regional and species-level migratory networks for a songbird, and we quantified forest loss in its Neotropical wintering range. Threats at temperate breeding sites have been well studied (e.g., Hames et al. 2002); however, with information on migratory connectivity, threats from winter habitat loss can now be quantified for specific breeding populations. Our study provides an operational framework to assess habitat loss and protection on the wintering grounds for both specific breeding populations and for a species as a whole.

\section{Methods}

\section{Geolocator Deployment and Data Analyses}

We deployed light-level geolocators $(n=733)$ on Wood Thrushes at 7 breeding sites and 4 wintering sites from 2007 to 2013 (Supporting Information) and obtained migration movement data for 102 individuals. In addition, one bird banded in Nicaragua was recovered on the breeding grounds. Geolocators were manufactured by British Antarctic Survey: MK14S (renamed MK5790 in 2013 and manufactured by BioTrack), $1.6 \mathrm{~g}, n=78$; MK10S, $1.1 \mathrm{~g}, n=9$; MK20S + radiotransmitter, $1.6 \mathrm{~g}$, $n=3$; and Lotek: LightBugs, $2 \mathrm{~g}, n=12$. We captured birds with mist nets and attached geolocators with a leg-loop backpack harness (Rappole \& Tipton 1991) of
Teflon ribbon (Stutchbury et al. 2009). The geolocator and harness weighed $<2.2 \mathrm{~g}$, or approximately $4.8 \%$ of the average Wood Thrush body mass (45.9 g [SD 4.3], $n=241$ ). Geolocator recovery rate varied by site (Supporting Information) due to differences in search effort and return rate of birds. The percentage of geolocator birds that returned carrying geolocators ranged from $23 \%$ to $38 \%$, but the percentage was not significantly lower than return rates of nongeolocator birds (Supporting Information). There were 2 cases of harness failure ( 1 in North Carolina and 1 in Vermont). We determined the sex of birds by breeding behavior and morphology or by amplifying sex-linked alleles from blood or feather samples following Griffiths et al. (1998). We used plumage characteristics to assign birds to age classes (first year vs. older) (Pyle 1997).

Geolocators record light levels every 2 or $10 \mathrm{~min}$ in relation to an internal timer, depending on model and year of production. This allows the determination of sunrise and sunset times and thus day length and solar midday and midnight, which are then used to estimate latitude and longitude with BASTrak software package (British Antarctic Survey). We used the "threshold method" to estimate location by, where at the light threshold chosen to define sunrise and sunset, the average angle of the sun on the horizon is determined from birds at known locations (details in Supporting Information). Average location error was $153 \mathrm{~km}$ in latitude and $121 \mathrm{~km}$ in longitude at breeding sites and 291 and $83 \mathrm{~km}$ at wintering sites (Supporting Information) (McKinnon et al. 2013b). Sample sizes differed among analyses due to missing data caused by geolocator battery failure, migration during equinoxes (when geolocators cannot determine latitude), or habitat or behavioral shading of the geolocator.

Breeding locations were defined by the average latitude and longitude for June and July, and winter sites were defined by the average latitude and longitude for January and February. To extract a conservative measure of migration route from our data, we examined the point when birds crossed the Gulf of Mexico (see Supporting Information for a map showing the Gulf of Mexico relative to the Wood Thrush range). Because longitude measurements from geolocators are more accurate than latitude measurements for this species (McKinnon et al. 2013b) (Supporting Information), we used longitude of fall exit from and spring reentry to the United States at the Gulf of Mexico (at approximately $30^{\circ} \mathrm{N}$ ) to represent the overall migration route. Therefore, in all of our subsequent analyses, each bird had a single longitude value associated with its fall or spring migratory route.

\section{Migratory Connectivity Networks}

We broadly defined breeding regions as northeast (north of Pennsylvania, U.S.A.; approximately $40-50^{\circ} \mathrm{N}$, 
$77-83^{\circ} \mathrm{W}$ ), central east (North Carolina to Pennsylvania; approximately $38-43^{\circ} \mathrm{N}, 67-78^{\circ} \mathrm{W}$ ), Midwest (Indiana south to Alabama, U.S.A., and westward, approximately $36-40^{\circ} \mathrm{N}, 85-94^{\circ} \mathrm{W}$ ), and southeast (South Carolina to Florida, U.S.A., approximately $30-38^{\circ} \mathrm{N}, 79-85^{\circ} \mathrm{W}$ ) (Supporting Information). We divided the wintering range into 3 regions according to longitude: western (Mexico excluding Yucatan state; $>92^{\circ} \mathrm{W}$ ), central (Yucatan, Mexico; Belize; Guatemala; El Salvador; and western Honduras; $87.5-92^{\circ} \mathrm{W}$ ), and eastern (eastern Honduras, Nicaragua, and Costa Rica, 82.5-87.5 $\mathrm{W}$ ) (Supporting Information). We did not track birds to or from Panama because Wood Thrush density there is low. We divided migration routes into categories spanning $5^{\circ}$ longitude along the northern Gulf of Mexico coast. For the regionallevel network, we used the number of birds tracked from each breeding and wintering site to quantify the strength of connectivity. For the species-level network, we used an estimate of relative abundance of Wood Thrushes in each breeding region to quantify the connectivity of Wood Thrush overall between breeding, migration, and winter sites.

Relative Wood Thrush abundance was determined using the number of individuals counted along standardized survey routes (Breeding Bird Survey, see Supporting Information for details) in each breeding region (Sauer et al. 2012), averaged from 2000 to 2010 . We then used global forest monitoring data (Hansen et al. 2008, 2010) to estimate total forest area within each breeding region (Table 1). The percentage of the entire Wood Thrush population occupying each breeding region was calculated as relative abundance multiplied by relative forest area in that region and then converted to a percentage of the total (Table 1). The strength of connections between each node determined by geolocator tracking (i.e., the regional network) was then adjusted according to the relative population size in each breeding region to create the species-level network.

\section{Habitat Mapping}

We used ArcMap10 (ESRI) to analyze forest cover and loss within the Wood Thrush breeding and wintering range by using data from a global forest monitoring database (http://globalmonitoring.sdstate.edu/projects/gfm)

(Hansen et al. 2008, 2010). Hansen et al. (2008, 2010) generated these data by integrating moderate spatial resolution $(250 \mathrm{~m}, 500 \mathrm{~m}$, and $1 \mathrm{~km})$ data from the Moderate Resolution Imaging Spectroradiometer (MODIS) and high-spatial-resolution Landsat Enhanced Thematic Mapper Plus (ETM+) data $(28.5 \mathrm{~m})$. Hansen et al. $(2008,2010)$ integrated data to estimate biome-scale forest change from 2000 to 2005 and MODIS data to identify regions of low, medium, and high probability of forest clearing. A stratified random sample of $18.5 \times$ $18.5 \mathrm{~km}$ blocks taken within these regions was interpreted for forest cover and forest clearing with high-spatial-resolution Landsat imagery from 2000 and 2005. To assess potential threats to Wood Thrushes from tropical deforestation, we quantified lowland humid tropical forest cover and extent of forest loss from data retrieved from the global forest monitoring database (Hansen et al. 2008, 2010) for 3 wintering regions defined for Wood Thrush (Supporting Information).

\section{Statistical Analyses}

We quantified the strength of connectivity between breeding and wintering locations by calculating the Mantel correlation coefficient $\left(r_{\mathrm{M}}\right)$ (Ambrosini et al. 2009; Cormier et al. 2013) with XLStat 2014 (Microsoft Corp.). We calculated a breeding and a wintering distance matrix (the distance between each individual and every other individual) based on the geographical coordinates of each individual bird's breeding and wintering sites with the Geographic Distance Matrix Generator version 1.2.3 (Ersts 2013). If individuals that breed close together also winter close together (i.e., the population shows strong connectivity), then a strong positive correlation is expected between the 2 matrices. The program uses a randomization procedure to estimate the expected distribution of $r(A B)$, where $A$ and $B$ are the distance matrices for the breeding and wintering locations. We set the number of random permutations to 10,000 to estimate the $P$ value of the observed correlation coefficient $r_{\mathrm{M}}$.

To determine if breeding and wintering sites for the same individuals followed a spatial pattern (e.g., leapfrog migration, where birds wintering farther north breed farther south, and the reverse) (Newton 2008) and if there was spatial structure in migration routes (e.g., birds breeding farther east migrated along a more easterly route), we used general linear models (GLMs) and multinomial logistic regressions in the program $R(R$ Development Core Team 2011). In the GLM analysis, breeding latitude and longitude were independent factors with winter latitude, winter longitude, and longitude at the northern Gulf coast as response variables. The multinomial regressions used the broad-scale breeding and wintering regions and the migratory nodes. Details and results of this more coarse-scale analysis are in the Supporting Information. We used a GLM to account for potential sex effects on breeding-wintering connectivity and migration route patterns and potential age effects on spring migration route (because some birds were juveniles and thus naïve spring migrants). We ran 4 models with the following dependent variables: winter latitude, winter longitude, fall route (longitude at gulf crossing), and spring route (longitude at gulf crossing). Independent factors included in the model were breeding location (both latitude and longitude), sex, and age (spring route only). We used a backward step procedure to drop 
Table 1. Habitat and population information on Wood Thrushes by North American breeding region.

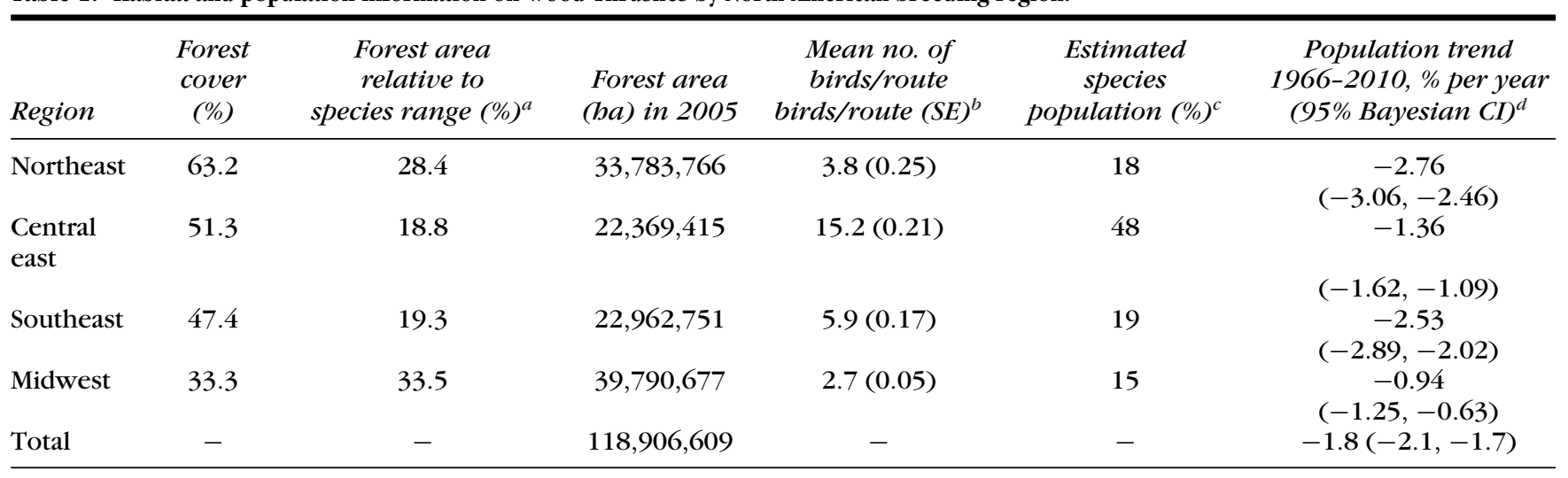

${ }^{a}$ Percent of the total forest area in each region divided by the total forest area within the entire range.

${ }^{b}$ Average abundance per year based on Breeding Bird Surveys from 2000 to 2010.

${ }^{c}$ Calculated by multiplying the average abundance of Wood Thrushes per region by the relative proportion of forest area in that region.

${ }^{d}$ Population trends within each region $(n=369,418,377$, and 782 routes, respectively) calculated with hierarchical Bayesian analysis of Breeding Bird Survey data.

factors from the full model one by one and evaluated the model fit with Akaike's Information Criterion.

\section{Results}

\section{Breeding-Wintering Migratory Connectivity}

Mapping migration destination $(n=103$, includes one band return) revealed moderate breeding-wintering connectivity (Fig. 1). Almost all (91\%; 32 of 35) Wood Thrushes tracked from northeastern and central eastern breeding populations wintered in a narrow region in the eastern part of the winter range (Fig. 1b) $\left(82.5-87.5^{\circ} \mathrm{W}\right)$. In contrast, most $(65 \% ; 11$ of 17$)$ birds tracked from southeastern or midwestern U.S. breeding populations traveled to the central winter range $\left(87.5-92^{\circ} \mathrm{W}\right)$ (Fig. 1c). Only 2 of 52 birds tracked from breeding sites wintered in the western wintering range in southern Mexico (both bred in the Midwest). Tracking via wintering deployments showed a similar pattern; none of the birds tracked from the central wintering region $(n=24)$ bred in the northeast, and birds tracked from the eastern winter region rarely (1 of 26) bred in the southeastern or midwestern breeding range (Figs. 1d-f).

The Mantel correlation coefficient indicated significant breeding-wintering connectivity in Wood Thrushes $\left(r_{\mathrm{M}}=0.33, n=103, P<0.0001\right)$. Birds tracked from our main breeding study sites (Pennsylvania and Indiana) were on average $319 \mathrm{~km}$ (SE 10.7) (range 15-1196 $\mathrm{km}$ ) apart from other individuals from the same breeding population during the winter. For Belize and Costa Rica deployments, individuals from the same winter population averaged $532 \mathrm{~km}$ (SE 22.1) (range 11-1611 km) apart in the breeding season. The GLMs indicated that winter latitude was predicted by breeding latitude $(\beta=-0.20$ [SE 0.07], $t=-2.74, P=0.007)$ and breeding longitude ( $\beta=0.33$ [SE 0.06], $t=5.60, P<0.001$ ), in that birds wintering farther south bred farther north and eastward (full model results in Table 2). Winter longitude was also predicted by breeding latitude $(\beta=-0.21$ [SE 0.08], $t=-2.78, P=0.006)$ and longitude $(\beta=0.25$ [SE 0.06], $t=4.06, P<0.001)$, in that birds wintering farther west bred farther south and west. These results corresponded to an overall broad pattern of parallel, leap-frog migration (Fig. 1). Sex was not retained as a factor in the model for wintering longitude or latitude (Table 2). Overall, breeding location (latitude + longitude) explained $31 \%$ of the variation in winter longitude $\left(r^{2}=0.31, F_{2,99}=22.61\right.$, $P<0.001)$ and $41 \%$ of the variation in winter latitude $\left(r^{2}=0.41, F_{2,99}=34.62, P<0.001\right)$. Results of a multinomial regression supported our GLM and Mantel test results (Supporting Information).

\section{Migration Route Connectivity}

In fall, migration route varied depending on breeding region; most individuals (83\%) from northeastern breeding populations migrated in fall through southern Florida and Cuba $\left(<83^{\circ} \mathrm{W}\right)$ (Fig. 2a), whereas only one quarter of midwestern and southeastern breeding populations used this route (Fig. 2c). In contrast, during spring migration, most wood thrushes from all breeding regions entered the United States along a relatively narrow stretch of the Gulf Coast $\left(88-93^{\circ} \mathrm{W}\right.$ ) (Figs. 2d-f). Breeding longitude was a significant factor predicting fall migration route ( $\beta=0.26$ [SE 0.10], $t=2.48, P<0.01$ ), in that birds breeding farther east also left the United States farther east. Breeding latitude and sex were not significant predictors of fall migration route (Table 2). The best model for spring migration route included breeding longitude and sex, but not age (first spring migration) or breeding latitude (Table 2). Despite that most birds traveled through a relatively narrow range of longitudes (88$93^{\circ} \mathrm{W}$ ) in spring, longitude of breeding destination was 
Table 2. Results of general linear models on wintering sites and migration routes for Wood Thrushes tracked with geolocators.

\begin{tabular}{|c|c|c|c|c|}
\hline \multirow[t]{3}{*}{ Winter latitude } & intercept & $-4.33(6.70)$ & -0.65 & 0.52 \\
\hline & breeding latitude $^{a}$ & $-0.20(0.07)$ & -2.74 & 0.007 \\
\hline & sex (male) & $-0.10(0.37)$ & -0.28 & 0.78 \\
\hline \multirow[t]{2}{*}{ Winter longitude } & intercept & $74.96(7.00)$ & 10.7 & $<0.001$ \\
\hline & breeding latitude $^{a}$ & $-0.21(0.08)$ & -2.77 & 0.006 \\
\hline \multirow[t]{4}{*}{ Fall route } & intercept & $57.03(6.60)$ & 8.62 & $<0.001$ \\
\hline & breeding latitude & $-0.12(0.12)$ & 1.05 & 0.30 \\
\hline & breeding longitude $^{a}$ & $0.34(0.08)$ & 4.05 & 0.001 \\
\hline & sex (male) & $-0.42(0.57)$ & -0.73 & 0.47 \\
\hline \multirow[t]{2}{*}{ Spring route } & intercept & $70.85(10.90)$ & 9.80 & $<0.001$ \\
\hline & breeding latitude & $0.03(0.11)$ & 0.29 & 0.77 \\
\hline
\end{tabular}

a Significant factor retained in the best model.

still a significant predictor of longitude at the U.S. Gulf Coast during spring migration ( $\beta=0.23$ [SE 0.10], $t=$ $2.30, P=0.02$ ). Birds breeding farther east crossed the Gulf of Mexico farther eastward. Controlling for breeding longitude, there was a tendency for females to travel farther west than males ( $\beta=1.07$ [SE 0.56], $t=1.90$, $P=0.06)$.

\section{Migratory Connectivity Network}

Spatial structure in connectivity and migratory routes was also evident in the regional and species-level migratory networks (Fig. 3). For instance, for the northeastern breeding region, $83 \%$ of individuals migrated through southern Florida $\left(<83^{\circ} \mathrm{W}\right)$ in fall, $96 \%$ occupied the eastern winter range, and $74 \%$ returned in spring via the central U.S. Gulf Coast $\left(88-93^{\circ} \mathrm{W}\right)$. In contrast, birds from the southeastern breeding region traveled primarily through the eastern Gulf of Mexico $\left(50 \% ; 83-88^{\circ} \mathrm{W}\right)$ fall migration route, and most (87\%) wintered in the central winter range. However, most southeastern breeding birds (60\%) also used the central route across the Gulf of Mexico in spring.

The species-level migratory network highlighted several areas of conservation importance for Wood Thrushes. The eastern wintering region was estimated to support $56 \%$ of the species, primarily (91\%) those from the northeastern and central eastern breeding regions (Fig. 3d). The central wintering region was used by $41 \%$ of all Wood Thrushes, which originated from breeding sites in the Midwest (9\%), south (16\%), and central east (14\%); few birds (1\%) in this wintering region originated from the northeast (Fig. 3d). A small proportion of all Wood Thrushes (3\%) was estimated to winter in the western nonbreeding range, and all of these birds bred in the Midwest (Fig. 3d). Fall and spring migration showed a loop migration pattern; no birds used the most westerly route in fall $\left(>93^{\circ} \mathrm{W}\right)$, and none used the most easterly route in spring $\left(<83^{\circ} \mathrm{W}\right)$ (Figs. $\left.3 \mathrm{e} \& 3 \mathrm{f}\right)$. In fall, the southern Florida route $\left(<83^{\circ} \mathrm{W}\right)$ was used by $52 \%$ of the species, and a third used the eastern U.S. Gulf coast $\left(83-88^{\circ} \mathrm{W}\right)$ (Fig. 3e). In spring, Wood Thrushes were even more concentrated; $73 \%$ of the species migrated northward through the central U.S. Gulf Coast (Fig. 3f), a span of $5^{\circ}$ in longitude (approximately $480 \mathrm{~km}$ ).

\section{Tropical Deforestation}

One of the key benefits of determining migratory connectivity is the ability to assess how potential threats on the wintering grounds vary among breeding regions. Wood Thrushes declined significantly throughout most of their breeding range (Fig. 4a), and the decline was the steepest in the northeastern and southeastern breeding regions (Table 1). The eastern winter range supported about half the species, and almost all northeastern breeders, yet this region contained only one-third of all available Wood Thrush wintering habitat (Fig. 4b; Supporting Information) and recent deforestation rates were $0.4 \%$ forest cover lost per year (Fig. 4c), a cumulative loss of approximately $2 \%$ of forest area in 5 years. Some sites in eastern Nicaragua had $15-35 \%$ forest loss (Fig. 4c). The central wintering region supported most southeastern breeders and contained the most extensive Wood Thrush habitat (50.6\%, Fig. 4b; Supporting Information) and a high deforestation rate ( $0.5 \% /$ year [Fig. $4 \mathrm{c}])$.

\section{Discussion}

A major challenge for conservation of migratory songbirds is determining the geographic connections 


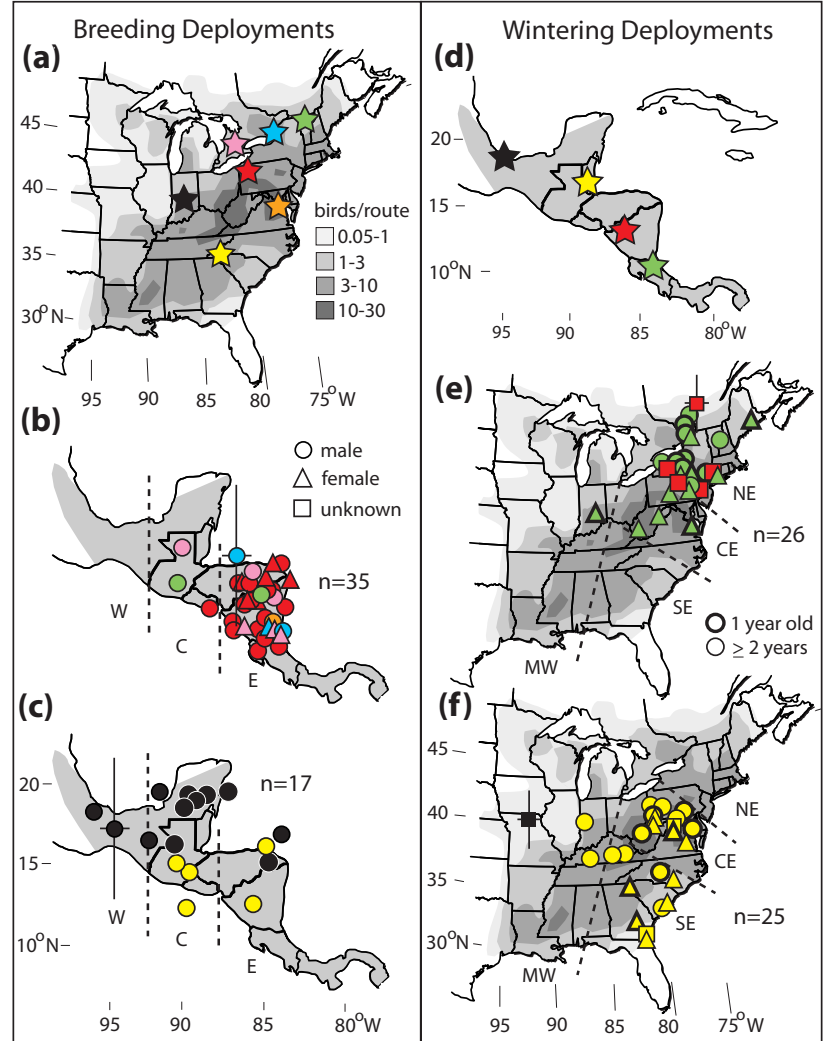

Figure 1. Migration destination of Wood Thrusbes tracked from (a) 7 breeding sites ( $n=52$ individuals) to $(b, c)$ their wintering sites in Central America and tracked from (d) 4 wintering sites $(n=50)$ to $(e, f)$ their breeding sites in North America. Origin and destination are color-coded for each bird by population. Gray shading is breeding and wintering range; 4 levels of shading on breeding range indicate relative abundance from Breeding Bird Survey (2007-2011) (Sauer et al. 2012). Data for the Nicaragua study site $(d, e)$ include one band recovery during the 2011 breeding season. Average error in latitude and longitude from ground-trutbing at deployment sites (McKinnon et al. 2013b) (Supporting Information) is shown with error bars for one individual location per panel $(b-f)$.

between declining breeding populations, their migratory routes, and their nonbreeding sites (Faaborg et al. 2010). We quantified, for the first time, geographic links across the entire annual cycle of a migratory songbird, including population-specific migration routes and breedingwintering connectivity. We found significant migratory connectivity structure for Wood Thrushes, where northeastern breeding populations migrated along more easterly routes in fall and wintered the farthest east (parallel migration) and south (leap-frog migration). In spring, however, there was weak connectivity as geographically distant breeding populations mixed extensively along a
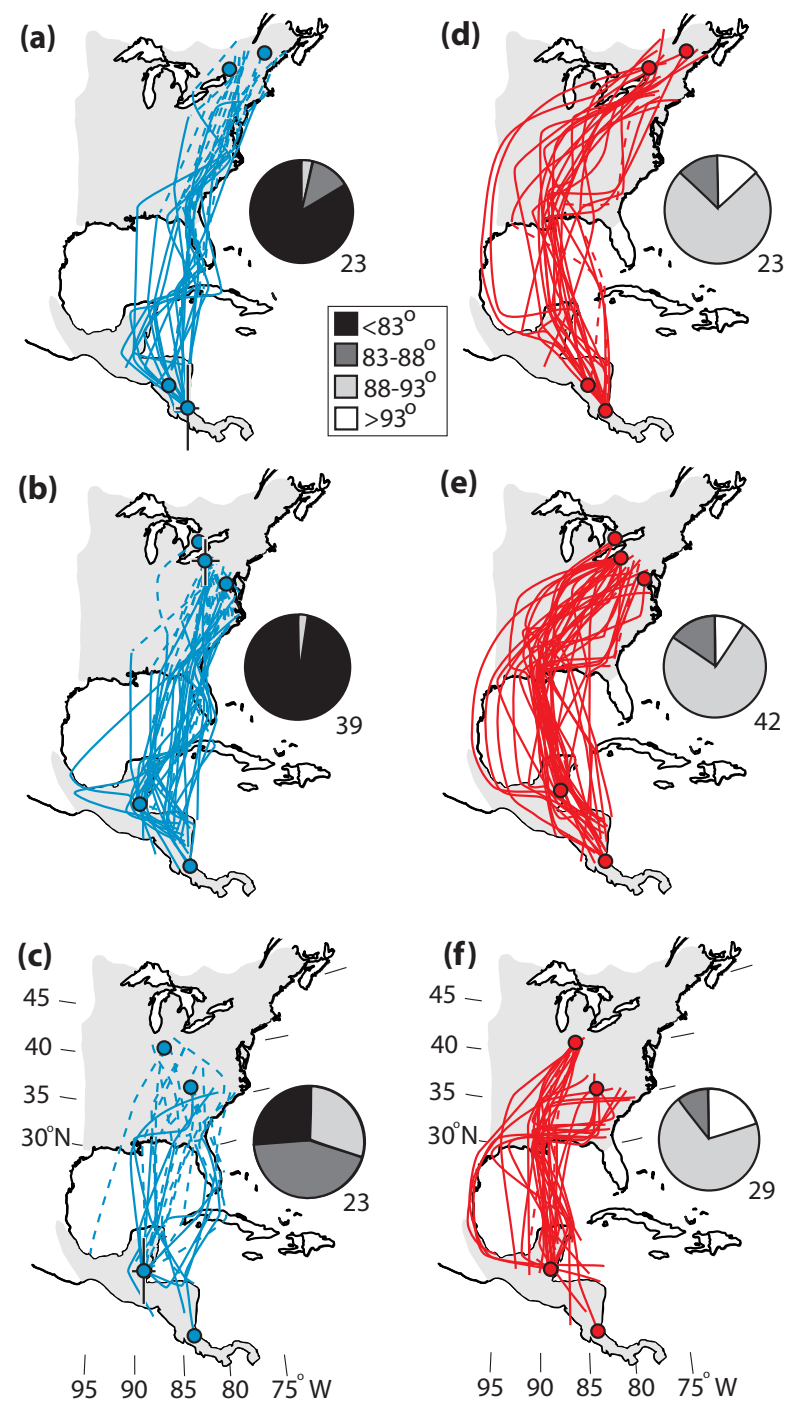

Figure 2. Estimated fall (blue) and spring (red) migration routes for Wood Thrushes that bred in (a, d) the northeast, $(b, e)$ central east, and $(c, f)$ southeast and Midwest breeding regions (gray shading,

breeding and wintering range; solid circles, geolocator deployment sites; line through circle, average location error from ground-trutbing [McKinnon et al. 2013b]; dasbed lines, migration movements where location is uncertain due to persistent shading or during fall or spring equinox when latitude cannot be resolved; pie charts, proportion of individuals in each breeding region making use of migration routes classified according to longitude along the U.S. Gulf coast; numbers next to pie charts, sample size).

similar migration route. These results emphasize the importance of measuring migratory connectivity throughout the annual cycle because breeding populations with distinct wintering regions may nevertheless share similar 
(a) Wintering (Regional)

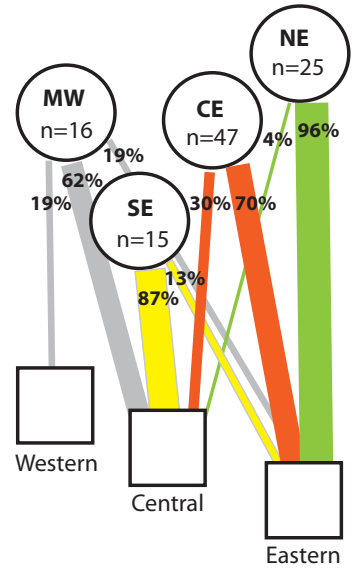

(b) Fall Route (Regional)

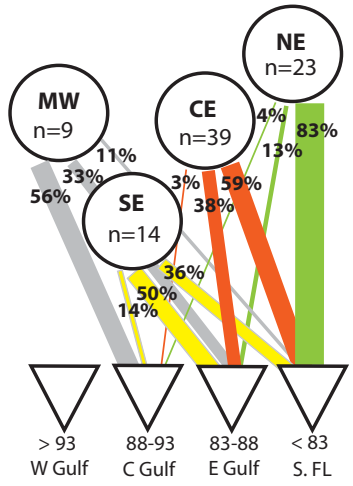

(c) Spring Route (Regional)

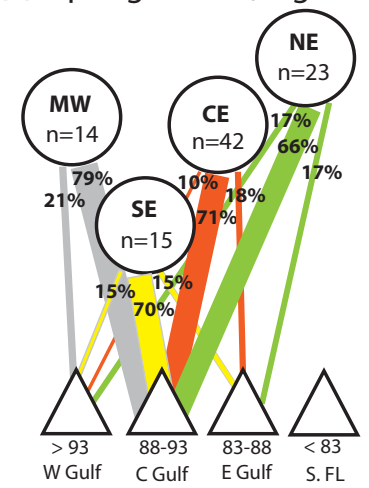

(d) Wintering (Species)

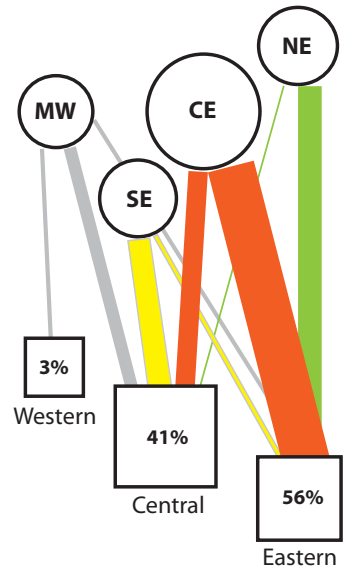

(e) Fall Route (Species)

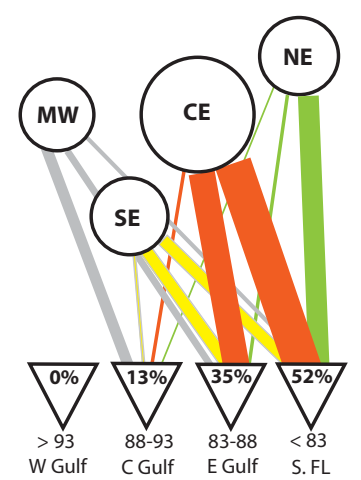

(f) Spring Route (Species)

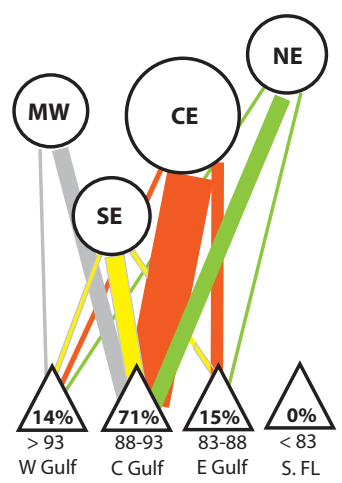

Figure 3. Migratory connectivity networks for Wood Thrush $(a, d)$ wintering sites and $(b, e)$ fall and $(c, f)$ spring migration routes. Regional networks (a-c) show for each breeding region (MW, Midwest; SE, soutbeast; $C E$, central east; NE, northeast) by color-coded lines the proportion (width of lines and percentages) of individuals tracked from that breeding region that travel to a particular winter region or migrate along a particular migration route in fall or spring (indicated by longitude, e.g., 88-93 C. Gulf $=88-93^{\circ} \mathrm{W}$, central Gulf of Mexico route) ( $n=$ number of birds tracked from that breeding region).

threats during migration when mortality risk is thought to be highest (Sillett \& Holmes 2002).

The migratory network we delineated provides a quantitative framework for prioritizing conservation efforts for Wood Thrushes along the entire 5,000-10,000 km migration journey. For example, habitat protection focused on the Mississippi River delta along the U.S. Gulf Coast $\left(83-88^{\circ} \mathrm{W}\right)$ would benefit Wood Thrushes primarily during spring migration and affect $73 \%$ of the total population of this declining species. In contrast, habitat protection in Florida or western Cuba $\left(<83^{\circ} \mathrm{W}\right)$ would affect wood thrushes almost exclusively during fall migration and affect primarily central eastern and northeastern breeding populations. This example illustrates the importance of migratory networks in identifying priority conservation areas, where limited conservation funds can be directed to conserve the greatest number of individuals.

The migratory network also highlights how decisions regarding where to best invest resources can differ depending on whether the goal is regional conservation of specific breeding populations or the species as whole. The species-level network suggests that the eastern wintering region should be a top conservation priority for Wood Thrush because it supports over half the species (Fig. 3d). This relatively small region still has extensive forest cover, but the rate of tropical deforestation is high (Figs. 4b \& 4c); for instance, Nicaragua lost 6.9\% of forest cover from 2000 to 2012 (Hansen et al. 2013). Conservation of forest via protected parks and promotion of rustic shade coffee (Bakermans et al. 2009; Philpott \& Bichier 2012) in this region would benefit the species overall and is critical for the northeastern breeding populations. The central wintering region was occupied by birds from a broader range of breeding populations (Figs. 3d and $4 \mathrm{~b}$ ), and therefore habitat loss in this region is

The species-level networks (d-f) indicate the estimated proportion of the entire Wood Thrush population that moves between a given breeding and nonbreeding site, taking into account regional breeding abundance (Table 1) (lines, color-coded by breeding origin [as in a-c]; width of line, proportional to the percentage of the global population traveling to a given nonbreeding site or using a given fall or spring route; values inside squares and triangles [i.e., nonbreeding sites], proportion of all wood thrushes that occupy that site; size of circle, proportional to entire breeding population (Table 1); size of wintering region squares in (d), relative area of bumid lowland forest cover in 2005 [Supporting Information]). [Correction added after online publication on October 30, 2014: Figure replaced, amending panel 3(b) to include a missing orange arrow under " $38 \%$ ", connecting the "CE" circle to the "E Gulf" triangle.] 

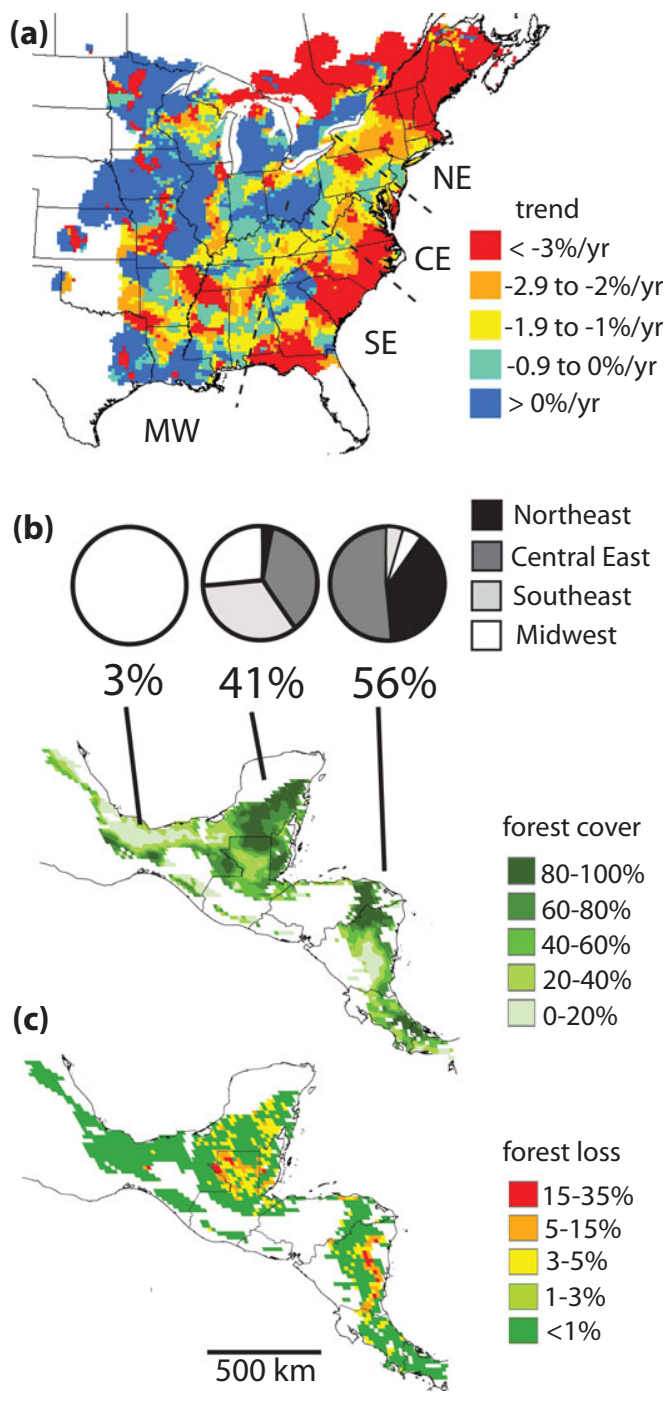

Figure 4. (a) Population trends of Wood Thrushes on their breeding grounds based on Breeding Bird Survey data (1966-2010; Sauer et al. 2012), (b) tropical forest cover in 2005 (Hansen et al. 2010) within the Wood Thrush winter range, and (c) deforestation in Mexico and Central America in the Wood Thrush wintering range from 2000 to 2005 (Hansen et al. 2008). Pie charts show the breeding population (northeast, central east, southeast, and Midwest) of individuals that wintered in a given region. Numbers below pie charts are the estimated percentage of the species that uses each winter region (Fig. 3d). Details of forest area and deforestation rates per region are in Supporting Information.

expected to have a diffuse effect on breeding populations. Guatemala has lost $8.2 \%$ of its tropical forest cover since 2000 and is considered a tropical deforestation hotspot (Hansen et al. 2013). Although few birds were tracked to the western wintering range in Mexico, this forest is nevertheless important at a regional level for conservation of midwestern breeding populations of Wood Thrushes.

A key conservation question is which fall and spring stopover regions have the greatest impact on fitness of migrating birds. In Wood Thrushes, annual adult survival is higher for central eastern and northeastern populations than for southeastern populations (Saracco et al. 2010), a pattern that could be due to differences in migratory routes. Most adults from the central east and northeast did not cross the Gulf of Mexico in fall; they migrated through Florida (Fig. 2e). It is not clear which is a riskier strategy, traversing an urbanized landscape in Florida or, as is the case for most southeastern birds, an open-water crossing of 800-1000 km during hurricane season. Field data on individual birds' refueling rates could be used to assess relative habitat quality along the migration routes we identified (e.g., Guglielmo et al. 2005; Seewagen et al. 2011). Radio tracking could be used to quantify survival or foraging behavior during migration (e.g., Ktitorov et al. 2010). It is not yet possible to measure mortality en route remotely because satellite transmitters are not small enough to be deployed on songbirds.

Quantitative estimates of migratory connectivity can be used in comparative studies of the ecological mechanisms that drive connectivity patterns and to test predictions about the consequences of migratory connectivity for population stability. Measured using the Mantel test, breeding-wintering connectivity for Wood Thrushes was higher $\left(r_{\mathrm{M}}=0.33\right)$ than that reported for European Barn Swallows (Hirundo rustica) $\left(r_{\mathrm{M}}=0.22\right)$ (Ambrosini et al. 2009) but less than that reported for coastal populations of Swainson's Thrush (Catharus ustulatus) $\left(r_{\mathrm{M}}=0.72\right)$ (Cormier et al. 2013), a species that segregates almost entirely on the wintering grounds. As more studies quantify connections between breeding and wintering sites of migratory songbirds, it will be possible to test if the strength of connectivity is a good predictor of specieslevel population declines.

Conservation managers can now be informed of the specific breeding, stopover, and wintering regions used by Wood Thrushes from specific breeding regions and which sites and routes are used most by the species overall. According to Breeding Bird Survey data, Wood Thrush populations have declined by an average of $1.8 \%$ /year (95\% CI -1.7 to -2.1 ) across the breeding range since 1966 (Fig. 4a) and by 3.2\%/year from 2001 to 2011 (95\% CI -3.8 to -2.7 ) (Sauer et al. 2012). Population modeling based on migratory networks parameterized with demographic estimates for each region, once available, can be used to explore different scenarios of habitat loss and protection to predict impacts on population trends (Faaborg et al. 2010) and prioritize conservation actions (Mattson et al. 2012). Migratory connectivity networks have the potential to revolutionize conservation strategies for migratory songbirds because one can finally see into, and measure, the contents of the so-called black box 
of the migration period (Taylor \& Norris 2010). A quantitative understanding of migratory connectivity within a migratory network framework can help conservation professionals better anticipate and respond to specieslevel consequences of environmental change at locations throughout the annual cycle.

\section{Acknowledgments}

We thank J. Sauer for analysis of Breeding Bird Survey data and S. Barretto for GIS analysis. We thank the following funding sources: Natural Sciences and Engineering Research Council of Canada, National Geographic Society, U.S. Fish and Wildlife Service Neotropical Migratory Bird Grant, Environment Canada, Schad Foundation, Kenneth M. Molson Foundation, York University, and proceeds from Silence of the Songbirds (Walker \& Co.). P.P.M., T.B.R., and C.E.S. received support from the Department of Defence's Legacy Program and the Strategic Environmental Research Development Program. The National Audubon Society provided funding and Pro-Aves Veracruz provided assistance for fieldwork in Mexico. Tropical fieldwork was conducted at the Belize Foundation for Research and Environmental Education, La Selva in Costa Rica, and Reserva Nebliselva El Jaguar in Nicaragua. We thank J. Marlin, J. Rotenberg, L. Duriaux-Chavarria, and G. Duriaux for field support in Central America.

\section{Supporting Information}

Theoretical patterns of migratory connectivity; information on geolocator and Breeding Bird Survey analyses; information on the multinomial logistic regression and its results; supplemental literature cited; information on geolocators deployed, thrush return rates, and geolocator accuracy; and forest area and forest loss within different regions of the Wood Thrush wintering range are available on-line. The authors are solely responsible for the content and functionality of these materials. Queries (other than absence of the material) should be directed to the corresponding author.

\section{Literature Cited}

Ambrosini, R., A. P. Moller, and N. Saino. 2009. A quantitative measure of migratory connectivity. Journal of Theoretical Biology 257:203211.

Bairlein, F., D. R. Norris, R. Nagel, M. Bulte, C. C. Voight, J. W. Fox, D. J. T. Hussell, and H. Schmaljohann. 2012. Cross-hemisphere migration of a 25g songbird. Biology Letters 2012:505-507.

Bakermans, M. H., A. C. Vitz, A. D. Rodewald, and C. G. Rengifo. 2009. Migratory songbird use of shade coffee in the Venezuelan Andes with implications for conservation of Cerulean Warbler. Biological Conservation 142:2476-2483.
Bell, C. P. 1997. Leap-frog migration in the fox sparrow: minimizing the cost of spring migration. Condor 99:470-477.

Cormier, R. L., D. L. Humple, T. Gardali, and N. E. Seavy. 2013. Light-level geologgers reveal strong migratory connectivity and within-winter movements for a coastal California Swainson's Thrush (Catharus ustulatus) population. Auk 130:283-290.

Delmore, K. E., J. W. Fox, and D. E. Irwin. 2012. Dramatic intraspecific differences in migratory routes, stopover sites and wintering areas, revealed using light-level geolocators. Proceedings of the Royal Society B-Biological Sciences 279:4582-4589.

Ersts, P. J. 2013. Geographic Distance Matrix Generator (version 1.2.3). American Museum of Natural History, Center for Biodiversity and Conservation, New York, NY. Available from http://biodiversityinformatics.amnh.org/open_source/gdmg (accessed July 2013).

Faaborg, J., et al. 2010. Conserving migratory land birds in the New World: Do we know enough? Ecological Applications 20:398-418.

Fraser, K. C., et al. 2012. Continent-wide tracking to determine migratory connetivity and tropical habitat associations of a declining aerial insectivore. Proceedings of the Royal Society B-Biological Sciences 279:4901-4906.

Fraser, K. C., et al. 2013. Consistent range-wide pattern in fall migration strategy of Purple Martin (Progne subis), despite different migration routes at the Gulf of Mexico. Auk 130:291-296.

Griffiths, R., M. C. Double, K. Orr, and R. J. G. Dawson. 1998. A DNA test to sex most birds. Molecular Ecology 7:1071-1075.

Guglielmo, C. G., D. J. Cerasale, and C. Eldermire. 2005. A field validation of plasma metabolite profiling to assess refueling performance of migratory birds. Physiological and Biochemical Zoology 78:116125.

Hames, R. S., K. V. Rosenberg, J. D. Lowe, S. E. Barker, and A. A. Dhondt. 2002. Adverse effects of acid rain on the distribution of the Wood Thrush Hylocichla mustelina in North America. Proceedings of the National Academy of Sciences of the United States of America 99:11235-11240.

Hansen, M. C., S. V. Stehman, and P. V. Potapov. 2010. Quantification of global gross forest cover loss. Proceedings of the National Academy of Sciences of the United States of America 107:8650-8655.

Hansen, M. C., et al. 2008. Humid tropical forest clearing from 2000 to 2005 quantified by using multitemporal and multiresolution remotely sensed data. Proceedings of the National Academy of Sciences of the United States of America 105:9439-9444.

Hansen, M. C., et al. 2013. High-resolution global maps of 21st-century forest cover change. Science 342:850-853.

Irwin, D. E., J. H. Irwin, and T. B. Smith. 2011. Genetic variation and seasonal migratory connectivity in Wilson's warblers (Wilsonia pusilla): species-level differences in nuclear DNA between western and eastern populations. Molecular Ecology 20:3102-3115.

Ktitorov, P., A. Tsvey, and A. Mukhin. 2010. The good and the bad stopover: behaviours of migrant reed warblers at two contrasting sites. Behavioral Ecology and Sociobiology 64:1135-1143.

Lesica, P., and F. W. Allendorf. 1995. When are peripheral-populations valuable for conservation. Conservation Biology 9:753-760.

Marra, P. P., D. R. Norris, S. M. Haig, M. S. Webster, and J. A. Royle. 2006. Migratory connectivity. Cambridge University Press, New York.

Martin, T. G., I. Chades, P. Arcese, P. P. Marra, H. P. Possingham, and D. R. Norris. 2007. Optimal conservation of migratory species. PLoS ONE 2 DOI: 10.1371/journal.pone.0000751.

Mattson, B. J., M. C. Runge, J. H. Devries, G. S. Boomer, J. M. Eadie, D. A. Haukos, J. P. Fleskes, D. N. Koons, W. E. Thogmartin, and R. G. Clark. 2012. A modeling framework for integrated harvest and habitat management of North American waterfowl: case-study of northern pintail metapopulation dynamics. Ecological Modelling 225:146-158.

McKinnon, E. A., K. C. Fraser, and B. J. M. Stutchbury. 2013a. New discoveries in landbird migration using geolocators and a flight plan for the future. Auk 130:1-12. 
McKinnon, E. A., C. Q. Stanley, K. C. Fraser, M. MacPherson, G. Casbourn, P. P. Marra, C. E. Studds, N. Diggs, and B. J. M. Stutchbury. $2013 b$. Estimating geolocator accuracy for a migratory songbird using live ground-truthing in tropical forest. Animal Migration 1:31-38.

Newton, I. 2008. The migration ecology of birds. Academic Press, London.

Norris, D. R., P. P. Marra, G. J. Bowen, L. M. Ratcliffe, J. A. Royle, and T. K. Kyser. 2006. Migratory connectivity of a widely distributed songbird, the American Redstart (Setophaga ruticilla). Ornithological Monographs 61:14-28.

Philpott, S. M., and P. Bichier. 2012. Effects of shade tree removal on birds in coffee agroecosystems in Chiapas, Mexico. Agriculture Ecosystems and Environment 149:171-180.

Pyle, P. 1997. Identification guide to North American birds. Volume I. Slate Creek Press, Bolinas, California.

R Development Core Team. 2011. R: a language and environment for statistical computing. R Foundation for Statistical Computing, Vienna, Austria.

Rappole, J. H., and A. R. Tipton. 1991. New harness design for attachment of radio transmitters to small passerines. Condor 62:335337.

Renfrew, R. B., D. Kim, N. Perlut, J. A. Smith, J. Fox, and P. P. Marra. 2013. Phenological matching across hemispheres in a long-distance migratory bird. Diversity and Distributions 19:1-12.

Rubenstein, D. R., C. P. Chamberlain, R. T. Holmes, M. P. Ayres, J. R. Waldbauer, G. R. Graves, and N. C. Tuross. 2002. Linking breeding and wintering ranges of a migratory songbird using stable isotopes. Science 295:1062-1065.

Runge, M., and P. P. Marra. 2005. Modeling seasonal interactions in the annual cycle of migratory birds. Pages 375-389 in R. Greenberg and
P. P. Marra, editors. Birds of two worlds: the ecology and evolution of migration. Johns Hopkins University Press, Baltimore.

Saracco, J. F., J. A. Royle, D. F. Desante, and B. Gardner. 2010. Modeling spatial variation in avian survival and residency probabilities. Ecology 91:1885-1891.

Sauer, J. R., J. E. Hines, J. E. Fallon, K. L. Pardieck, D. J. Ziolkowski Jr., and W. A. Link. 2012. The North American Breeding Bird Survey, results and analysis 1966-2010. Version 12.07.2012. USGS Patuxent Wildlife Research Center, Laurel, Maryland.

Seewagen, C. L., C. D. Sheppard, E. J. Slayton, and C. G. Guglielmo. 2011. Plasma metabolites and mass changes of migratory landbirds indicate adequate stopover refueling in a heavily urbanized landscape. Condor 113:284-297.

Sherry, T. W., and R. T. Holmes. 1996. Winter habitat quality, population limitation, and conservation of Neotropical Nearctic migrant birds. Ecology 77:36-48

Sillett, T. S., and R. T. Holmes. 2002. Variation in survivorship of a migratory songbird throughout its annual cycle. Journal of Animal Ecology 71:296-308.

Sillett, T. S., R. T. Holmes, and T. W. Sherry. 2000. Impacts of a global climate cycle on population dynamics of a migratory songbird. Science 288:2040-2042.

Stutchbury, B. J. M., S. A. Tarof, T. Done, E. Gow, P. M. Kramer, J. Tautin, J. W. Fox, and V. Afanasyev. 2009. Tracking long-distance songbird migration by using geolocators. Science 323:896.

Taylor, C. M., and D. R. Norris. 2010. Population dynamics in migratory networks. Theoretical Ecology 3:65-73.

Webster, M. S., P. P. Marra, S. M. Haig, S. Bensch, and R. T. Holmes. 2002. Links between worlds: unraveling migratory connectivity. Trends in Ecology \& Evolution 17:76-83.

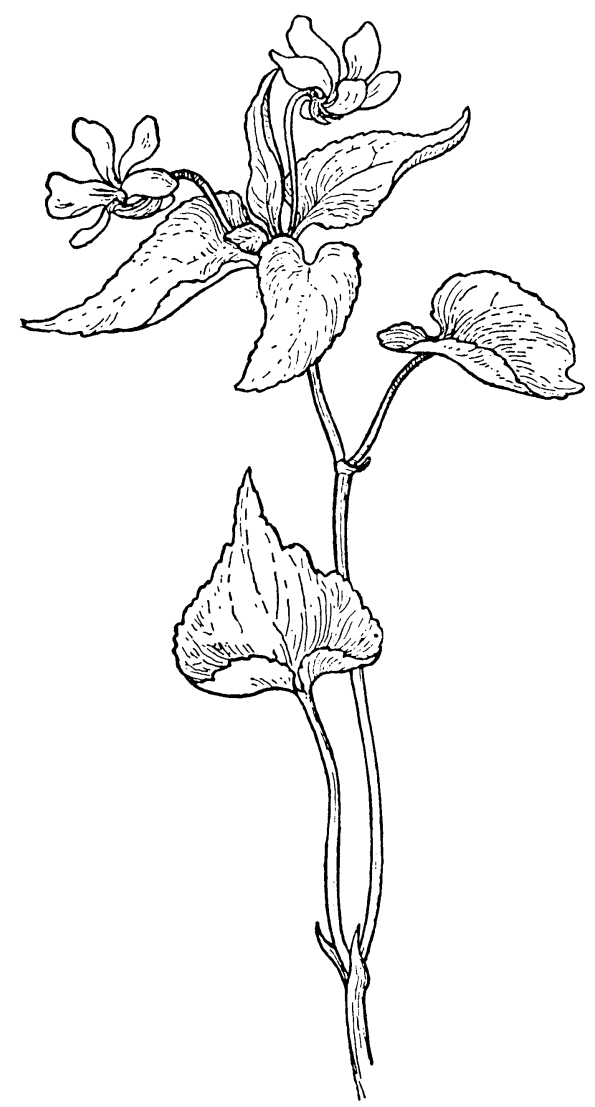

